\title{
Effect of exogenous insulin on plasma and follicular insulin-like growth factor I, insulin-like growth factor binding protein activity, follicular oestradiol and progesterone, and follicular growth in superovulated Angus and Brahman cows
}

\author{
R. B. Simpson ${ }^{1 *}$, C. C. Chase, Jr ${ }^{1 \dagger}$, L. J. Spicer ${ }^{2}$, R. K. Vernon ${ }^{2}$, \\ A. C. Hammond ${ }^{1}$ and D. O. Rae ${ }^{3}$ \\ ${ }^{1}$ USDA, Agricultural Research Service, Brooksville, FL 34601-4672, USA; ${ }^{2}$ Department of Animal \\ Science, Oklahoma State University, Stillwater, OK 74078, USA; and ${ }^{3}$ College of Veterinary Medicine, \\ University of Florida, Gainesville, FL 32610, USA
}

Angus ( $n=14)$ and Brahman $(n=14)$ cows were used to evaluate the effects of insulin administered concomitantly with FSH in a superovulation regimen. Cows were allotted to four pen replicates by treatment and breed, and received FSH (i.m.) twice a day for 5 consecutive days (first day of injections $=$ day 0 of study) plus concomitant administration of either saline (control) or long-acting bovine insulin $\left(0.25 \mathrm{iu} \mathrm{kg}^{-1}\right.$ body mass; s.c.). Blood samples were collected at intervals of $6 \mathrm{~h}$ during the injection period and analysed for plasma insulin, glucose, insulin-like growth factor I (IGF-I) and IGF-I binding protein (IGFBP) activity. Cows were ovariectomized on day 5. The number and diameter of follicles were recorded. Follicular fluid was aspirated for determination of IGF-I, IGFBP activity, oestradiol and progesterone. Mean plasma concentration of glucose was lower in insulin-treated than in control cows averaged over days $1-5$ (56 \pm 3 versus $82 \pm 3 \mathrm{mg} \mathrm{dl}^{-1} ; P<0.01$ ). Plasma concentration of IGF-I and IGFBP activity were not affected $(P>0.10)$ by treatment, but were higher in Brahman than in Angus cows (IGF-I: $41 \pm 6$ versus $19 \pm 6 \mathrm{ng} \mathrm{ml}^{-1}, P<0.05$; IGFBP activity: $17.5 \pm 0.4$ versus $15.8 \pm 0.04 \%$ $\left.(10 \mu \mathrm{l})^{-1} ; P<0.03\right)$. Insulin treatment did not affect the number of small $(1.0-3.9 \mathrm{~mm})$, medium $(4.0-7.9 \mathrm{~mm})$ or large $(\geq 8.0 \mathrm{~mm})$ follicles. Brahman cows had a greater $(P<0.01)$ number of medium and total follicles (19.4 \pm 2.5 and $60.5 \pm 5.5$, respectively) than did Angus cows (7.5 \pm 2.6 and $30.5 \pm 5.6$, respectively). Diameter of large follicles was greater in insulin-treated than in control cows (11.4 \pm 0.2 versus $10.6 \pm 0.1 \mathrm{~mm}$; $P<0.05)$. Follicular fluid IGF-I concentration in large follicles was higher in insulin-treated Brahman cows $\left(60 \pm 2 \mathrm{ng} \mathrm{ml}^{-1}\right)$ than in control Brahman cows $\left(37 \pm 2 \mathrm{ng} \mathrm{ml}^{-1}\right)$, but was lower in insulin-treated Angus cows $\left(31 \pm 3 \mathrm{ng} \mathrm{ml}^{-1}\right)$ than in control Angus cows (38 $\pm 2 \mathrm{ng} \mathrm{ml}^{-1}$; treatment $x$ breed interaction, $P<0.01$ ). IGFBP activity in fluid from large follicles was not affected by insulin treatment in Brahman cows but was reduced $(P<0.05)$ by insulin treatment in Angus cows. In large follicles, concentration of oestradiol in follicular fluid was higher in insulin-treated than in control cows (144 \pm 36 versus $29 \pm 28 \mathrm{ng} \mathrm{ml}^{-1} ; P<0.10$ ), while progesterone concentration was lower in insulin-treated than in control cows $\left(71 \pm 24\right.$ versus $\left.178 \pm 19 \mathrm{ng} \mathrm{ml}^{-1} ; P<0.05\right)$. The percentage of large follicles that were oestrogen-active was higher $(P<0.05)$ in insulintreated cows $(54 \pm 4.9 \%)$ than in control cows $(25 \pm 4.5 \%)$. In summary, insulin treatment resulted in increased follicle diameter, higher oestradiol and lower progesterone concentrations in the fluid of large follicles, but did not increase the number of follicles. Brahman cows had higher plasma and follicular fluid concentrations of IGF-I, lower oestradiol concentrations and a greater number of follicles than did Angus cows.

\footnotetext{
*Present address: Department of Animal Science, University of Arkansas, Southwest Research and Extension Center, Hope, AR 71801, USA. ${ }^{\dagger}$ Correspondence: 22271 Chinsegut Hill Road, Brooksville, FL 34601-4672, USA

Revised manuscript received 14 July 1994
} 


\section{Introduction}

Superovulation and embryo transfer have allowed the cattle industry to accelerate the production of genetically superior animals. A critical component for success of this procedure is the ovulatory response of donor cows to superovulation treatment. Any additional or concomitant treatments that would consistently enhance the ovulatory response of donor cows would be of interest to the industry.

The metabolic actions of insulin have been widely studied (Prior and Smith, 1983; Czech, 1984) with recent interest directed towards the possible direct involvement of insulin in reproductive functions (Poretsky and Kalin, 1987). Insulin stimulates glucose uptake, general metabolism and mitosis of cultured, bovine granulosa cells (Allen $e t$ al., 1981; Savion $e$ al., 1981; Langhout et al., 1991) and is an important mitogen involved in the growth of cultured bovine follicles (Peluso and Hirschel, 1987).

Experiments evaluating the effects of insulin on reproduction in vivo have yielded mixed results; injections of insulin before mating had no effect on the interval to breeding or pregnancy rate in mixed-parity Suffolk ewes (Kirkwood et al., 1991). Administration of insulin increased ovulation rate in cyclic gilts (Cox et al., 1987), and this response seemed to be independent of any changes in gonadotrophin concentrations, indicating a possible direct effect of insulin on the ovary. The most consistent effect of exogenous insulin in gilts is a marked reduction in atresia of medium-sized (Matamoros et al., 1990) and small (Matamoros et al., 1991) follicles. Pulsatile infusion of bovine insulin increased the ovulation rate in response to FSH in energy-deprived heifers (Harrison and Randel, 1986). Administration of insulin to pregnant males' serum gonadotrophin (PMSG)-treated prepubertal gilts almost doubled the concentration of insulin-like growth factor I (IGF-I) in the fluid of medium-sized follicles, but did not affect peripheral concentrations (Matamoros et al., 1991). However, the effect of exogenous insulin on blood or follicular fluid IGF-I or IGF binding protein (IGFBP) activity has not been evaluated in cattle. IGF-I and IGFBP are thought to be important intraovarian regulators of follicular function (Hammond et al., 1991; Guidice, 1992).

In addition to determining specific effects of insulin on follicles, it is also important to assess differences in ovulatory response due to breed. Bos indicus cattle are important to beef production in the tropics and subtropics. Although differences in endocrine control of reproduction between Bos indicus and Bos taurus have been reported (Randel, 1984), relatively few studies have included direct comparisons of the reproductive characteristics between these two species. Peacock et al. (1971 and 1977) reported higher pregnancy rates in Brahman than in Angus or Shorthorn cows in subtropical Florida. In contrast, Reynolds et al. (1979) found higher pregnancy rates, at first service, in Angus than in Brahman cows in semitropical conditions. It is not known how, if at all, Bos indicus and Bos taurus differ in their response to superovulation regimens, with or without insulin.

The objectives of the study reported here were to determine the effect of insulin (administered concomitantly with FSH) on hormonal and ovarian characteristics of cows and to compare these characteristics in Angus and Brahman cows, during and after superovulation.
Materials and Methods

\section{Animals and treatments}

Mature Angus $(n=14)$ and Brahman $(n=14)$ cows were used. On day -22 (day $0=$ first day of FSH administration), the cows were placed into drylot pens ( 7 cows per pen) with treatments and breeds stratified across pens. Cows were given access to mixed perennial peanut (Arachis glabrata Benth)-grass hay ( $10.7 \%$ crude protein) ad libitum. On day -21 , all cows received an ear implant (6 $\mathrm{mg}$ norgestomet) s.c. and an i.m. injection containing norgestomet $(3 \mathrm{mg}$ ) and oestradial valerate $(5 \mathrm{mg}$ ) to synchronize oestrus (Syncro-Mate-B, Sanofi Animal Health, Inc., Overland Park, KS). On day -12 , implants were removed and cows were given $25 \mathrm{mg} \mathrm{PGF}$ i.m. (Lutalyse, The Upjohn Co., Kalamazoo, MI) to ensure luteolysis.

All cows were subjected to a 5 day superovulation regimen (Staigmiller et al., 1979) using a total of $40 \mathrm{mg}$ FSH (Schering-Plough Animal Health Corp., Kenilworth, NJ) given i.m. in decreasing amounts over 5 days (day $0-4$ ). The dose sequence of FSH administered was: days 0 and $1,5 \mathrm{mg}$ per injection; days 2 and 3, $3.75 \mathrm{mg}$ per injection; day $4,2.5 \mathrm{mg}$ per injection. FSH injections were given at 07:00 and 19:00 h on each day. On day 3 of the superovulation treatment, each cow received injections $(25 \mathrm{mg}$ i.m. at $07: 00 \mathrm{~h}$ and $15 \mathrm{mg}$ at 19:00 h) of $\mathrm{PGF}_{2 u}$.

Concomitant with each FSH injection, cows were given (s.c.) saline (control; Angus, $n=7$; Brahman, $n=7$ ) or long-acting bovine insulin (100 iu ml ${ }^{-1} ; 0.25 \mathrm{iu} \mathrm{kg}^{-1}$ body mass; Lente, Novo Nordisk Pharmaceuticals, Inc., Princeton, NJ; Angus, $n=7$; Brahman, $n=7$ ). In humans, the insulin product used produces an effect beginning approximately $2.5 \mathrm{~h}$ after injection, with maximum effect between 7 and $15 \mathrm{~h}$ ending approximately $24 \mathrm{~h}$ after injection. Mean body mass of each cow on day -2 and day -1 was used to determine the total amount of insulin or vehicle administered. Body masses were also recorded on day 5 .

\section{Sample collection}

Single blood samples were collected for determination of plasma concentrations of glucose and IGF-1, at intervals of $6 \mathrm{~h}$ throughout the 5 day injection period. Samples taken at 07:00 and 19:00 h were collected immediately before $\mathrm{FSH}$ and insulin or saline injections. Plasma concentrations of insulin were determined from samples taken at 07:00, 13:00 and 19:00 h on days 0,2 and 4, respectively, and at 01:00 h on days 1,3 and 5 , respectively, of the injection period. Plasma samples collected at $07: 00 \mathrm{~h}$ on days $0-5$ were used to determine IGFBP activity.

On day $5,12-24 \mathrm{~h}$ before anticipated ovulation, ovariectomies were performed on each cow. Ovaries were removed via high lumbar laparotomy, with the cows restrained in a hydraulic squeeze chute. An incision was made using sterile procedures under local anaesthesia with $2 \%$ lidocaine hydrochloride (30-40 ml; Butler Co., Columbus, $\mathrm{OH}$ ). Ovaries were placed on ice immediately after ovariectomy and were processed in the laboratory within $4 \mathrm{~h}$ after removal. Connective tissue and mesovarium were removed and ovaries were weighed. The external diameter of surface follicles was 
measured and categorized as small (1.0-3.9 mm), medium (4-7.9 mm) or large ( $\geq 8 \mathrm{~mm}$ ) (Spicer and Enright, 1991). Follicular fluid was aspirated from follicles and the fluid volume was recorded for each follicle.

Fluid from small follicles was combined into a pool for each ovary. Owing to the large number of follicles, fluid from follicles with diameters of $4.0-6.9 \mathrm{~mm}$ was pooled for each ovary, but fluid from follicles $\geq 7.0 \mathrm{~mm}$ was stored individually at $-20^{\circ} \mathrm{C}$.

Follicular fluid was analysed for concentrations of IGF-I, oestradiol, progesterone and IGFBP activity. In large follicles, from which the quantity of fluid was sufficient for determination of oestradiol and progesterone concentrations, oestradiol:progesterone ratios were calculated by dividing follicular fluid concentrations of oestradiol by follicular fluid concentrations of progesterone. Large follicles with oestradiol: progesterone ratios greater than one were defined as oestrogen-active; conversely, large follicles with oestradiol: progesterone ratios less than one were defined as oestrogeninactive (Spicer et al., 1988).

\section{Assays}

Plasma concentrations of glucose were determined by an automated method (Industrial Method 339-19; Technicon Industrial Systems, Tarrytown, NY) based on the glucose oxidase procedure described by Gochman and Schmitz (1972). Plasma concentrations of insulin were determined using a solid-phase insulin radioimmunoassay kit (Micromedic Insulin Kit, ICN Biomedicals, Costa Mesa, CA) as per instructions except that bovine insulin was used as a reference standard

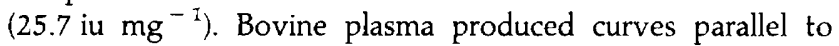
standard curves when added at increasing volumes. Intra- and interassay coefficients of variation for the three assays were 7.5 and $13.3 \%$, respectively. Sensitivity of the insulin assay, defined as $90 \%$ of total binding, was $0.11 \mathrm{ng} \mathrm{ml}^{-1}$.

Concentrations of IGF-I in plasma and follicular fluid were determined by radioimmunoassay after acid-ethanol extraction as described by Echternkamp et al. (1990). Intra- and interassay coefficients of variation for five plasma IGF-I assays were 7.5 and $13.0 \%$, respectively, and for seven follicular fluid IGF-I assays were 14.8 and $20.4 \%$, respectively. Sensitivity of the assay, as previously defined, was $3.3 \mathrm{pg}$ per tube. Total IGFBP activity in plasma or follicular fluid was determined after incubation with ${ }^{125}$ I-labelled IGF-I by the method of Moses et al. (1979). Briefly, $10 \mu \mathrm{l}$ aliquots of plasma or follicular fluid were incubated overnight at $4^{\circ} \mathrm{C}$ with $100 \mu{ }^{125}$ I-labelled IGF-I ( 15000 c.p.m.; counter efficiency was $75 \%$ ) and $150 \mu$ l of assay buffer (PBS containing $2.5 \mathrm{mg} \mathrm{BSA} \mathrm{ml}^{-1}, \mathrm{pH} 7.5$ ). Activated charcoal $\left(500 \mu \mathrm{l} ; 5 \% \mathrm{w} / \mathrm{v}\right.$ in PBS containing $\left.2.5 \mathrm{mg} \mathrm{BSA} \mathrm{ml}^{-1}\right)$ was added to each tube to separate bound from free ${ }^{125} \mathrm{I}$ labelled IGF-I, and the tubes were incubated for $30 \mathrm{~min}$ at $4^{\circ} \mathrm{C}$, and centrifuged at $1200 \mathrm{~g}$ for $20 \mathrm{~min}$ at $4^{\circ} \mathrm{C}$. Intra- and interassay coefficients of variation were 5.2 and $7.8 \%$, respectively, for 15 serum assays, and 3.8 and $7.4 \%$, respectively, for nine follicular fluid assays.

Follicular fluid concentrations of oestradiol were analysed using radioimmunoassay procedures reported by Spicer and Enright (1991). Intra- and interassay coefficients of variation for eight assays were 13.6 and $28.9 \%$, respectively. Sensitivity, as previously defined, was $0.27 \mathrm{pg}$ per tube. Follicular fluid concentrations of progesterone were determined using procedures reported by Spicer and Enright (1991). Intra- and interassay coefficients of variation for eight assays were 18.4 and $24.6 \%$, respectively. Sensitivity of the progesterone assay was $0.028 \mathrm{ng}$ per tube.

\section{Statistical analyses}

All analyses were conducted using the GLM Procedure (SAS, 1985). Plasma insulin, glucose, IGF-I and IGFBP activity were analysed using a split-split plot design with treatment as the main effect, breed the subplot and day of experiment and time of day the sub-subplots. Follicular fluid hormone data, number of follicles and ovarian measurements at the time of ovariectomy were analysed using a split-plot design with treatment as the main effect and breed the subplot. Concentrations of hormones in medium follicles were averaged among the pooled $(4.0$ to $6.9 \mathrm{~mm})$ and single-sample $(7.0$ to $7.9 \mathrm{~mm}$ ) follicles for statistical analyses. The number of follicles per cow was used as a covariate in the model for mean paired ovarian mass. Owing to heterogeneous variance in follicular fluid steroid concentrations, logarithmic transformations were performed on values for follicular fluid concentrations of oestradiol and progesterone using the formulae [natural log (oestradiol +1$)$ ] and [natural log (progesterone +1$)$ ], respectively. Transformed values were used for statistical analyses; however, absolute data are reported herein. Multivariate analysis of variance (MANOVA; SAS, 1985) was used to evaluate the relationship between follicle diameter and volume, mean plasma IGF-I on day 4 of the study, follicular fluid IGF-I, IGFBP activity, oestradiol, progesterone and oestradiol:progesterone ratio.

A similar split-plot model was used to analyse data for follicular fluid IGF-I, IGFBP activity, oestradiol and progesterone and the oestradiol:progesterone ratio within oestrogenactive and oestrogen-inactive follicles. Follicle diameter was used as a covariate in this model and, when not significant as a covariate, was deleted from subsequent analyses. Within oestrogen-active and oestrogen-inactive follicles, MANOVA (SAS, 1985) was used to evaluate the relationship between follicle diameter and volume, and mean plasma IGF-I on day 4 of the study, follicular fluid concentrations of IGF-I, IGFBP activity, oestradiol and progesterone, and oestradiol:progesterone ratio. Means for all data are reported as least-squares means.

\section{Results}

\section{Body mass and blood components}

Neither treatment, breed nor day of experiment contributed to variation in body mass of cows. No treatment $x$ day of experiment or breed $x$ day of experiment interactions were detected for body mass. Mean change in body mass from pretreatment (mean body mass of days -2 and -1 ) to ovariectomy (day 5) was greater in Brahman than in Angus cows $(-25 \pm 4.4$ versus $-9 \pm 4.5 \mathrm{~kg} ; P<0.05)$. 
(a)

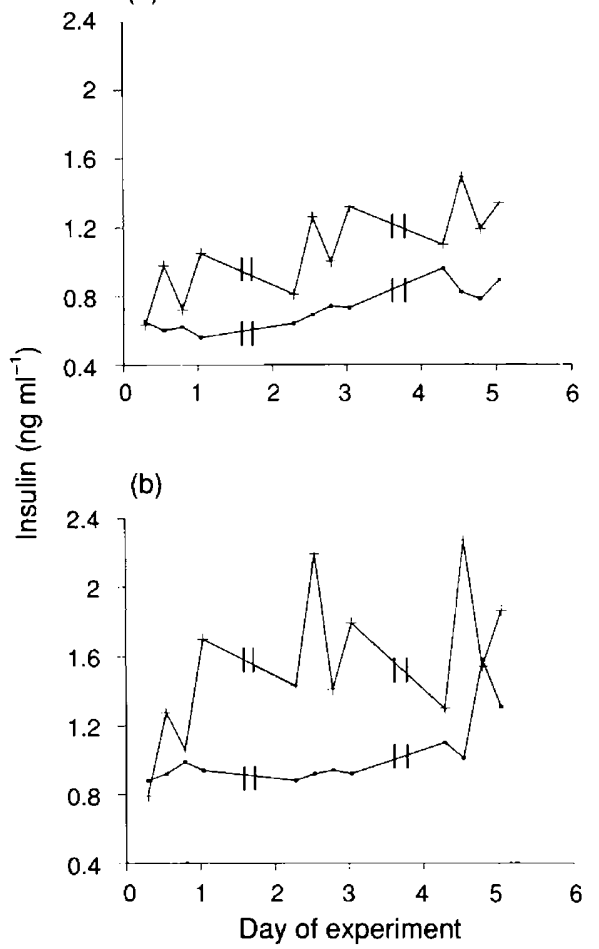

Fig. 1. Least-squares mean plasma concentrations $\left(\mathrm{ng} \mathrm{ml}^{-1}\right)$ of insulin at 07:00, 13:00, 19:00 h (days 0, 2 and 4) and 01:00 h (days 1, 3 and 5) in (a) Angus and (b) Brahman cows. Cows received FSH i.m. at 07:00 and 19:00 h for 5 consecutive days (days 0-4) with concomitant s.c. administration of $(\omega)$ saline $(n=14)$ or $(+)$ long-acting bovine insulin $\left(0.25 \mathrm{iu} \mathrm{kg}^{-1}\right.$ body mass; $\left.n=14\right)$. A treatment $x$ day of injection interaction $(P<0.01)$ was detected for plasma insulin. Pooled SEM: Angus and Brahman controls $=0.11$; Angus and Brahman insulin treated $=0.14$.

Plasma insulin was similar $(P>0.10)$ between treatments at the beginning of the injection period $(07: 00 \mathrm{~h}$ on day 0$)$, but tended to be higher in insulin-treated than in control cows over the injection period $\left(1.31 \pm 0.04\right.$ versus $0.88 \pm 0.04 \mathrm{ng} \mathrm{ml}^{-1}$; $P<0.10$; Fig. 1). A treatment $\times$ time of day interaction was detected $(P<0.01)$ for plasma insulin, as insulin concentrations were greater $(P<0.01)$ at $13: 00$ and $01: 00 \mathrm{~h}$ than at 07:00 and 19:00 $\mathrm{h}$ in insulin-treated cows, but were similar $(P<0.10)$ for all times in control cows. Brahman cows ( $1.29 \pm 0.08 \mathrm{ng} \mathrm{ml}^{-1}$ ) had higher $(P=0.07)$ plasma insulin concentrations than did Angus cows $\left(0.90 \pm 0.08 \mathrm{ng} \mathrm{ml}^{-1}\right)$.

Plasma concentration of glucose was lower in insulintreated than in control cows on all days except day 0 (Fig. 2; treatment $x$ day of injection interaction, $P<0.01$ ). A breed $\times$ day of injection interaction was also detected $(P<0.01)$ for glucose concentrations as glucose in Brahman cows fell up to day 2 and then levelled off on day 3, whereas glucose in Angus cows continued to decline up to day 4 .

Mean plasma concentration of IGF-I during the 5-day injection period was similar in control $\left(29 \pm 4 \mathrm{ng} \mathrm{ml}^{-1}\right)$ and insulin-treated (31 $\left.\pm 4 \mathrm{ng} \mathrm{ml}^{-1}\right)$ cows, but was higher $(P<0.05)$ in Brahman $\left(41 \pm 6 \mathrm{ng} \mathrm{ml}^{-1}\right)$ than in Angus (19 $\pm 6 \mathrm{ng} \mathrm{ml}^{-1}$ ) cows. As with plasma IGF-I, plasma total IGFBP activity (percentage of binding per $10 \mu \mathrm{l}$ ) was similar in (a)

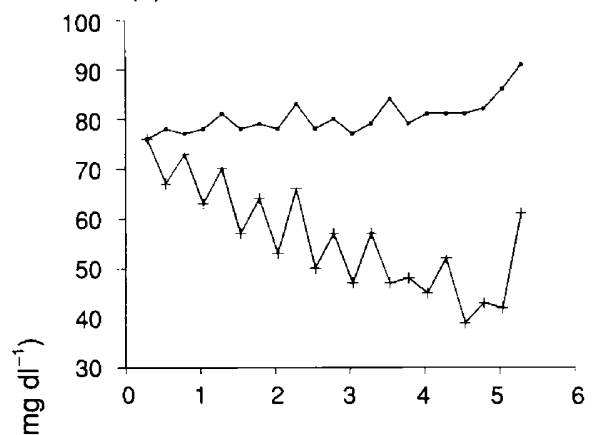

(b)

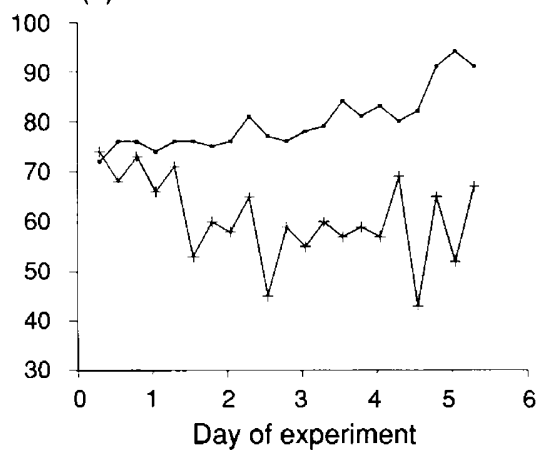

Fig. 2. Least-squares mean plasma concentrations $\left(\mathrm{mg} \mathrm{dl}^{-1}\right)$ of glucose in (a) Angus and (b) Brahman cows from samples collected at intervals of $6 \mathrm{~h}$ during the 5 day injection period. Cows received FSH i.m. at $07: 00$ and 19:00 h for 5 consecutive days (days $0-4$ ) with concomitant s.c. administration of $(-)$ saline $(n=14)$ or $(+)$ long-acting bovine insulin $\left(0.25 \mathrm{iu} \mathrm{kg}^{-\mathrm{I}}\right.$ body mass; $\left.n=14\right)$. Pooled SEM: Angus and Brahman controls $=2.0 ;$ Angus and Brahman insulin-treated $=5.0$.

control (16.3) and insulin-treated (16.9) cows, and was higher $(P<0.03)$ in Brahman (17.5 \pm 0.4$)$ than in Angus (15.8 \pm 0.4$)$ cows. Plasma IGF-I $\left(\mathrm{ng} \mathrm{ml}^{-1}\right)$ was higher $(P<0.05)$ on days 4 and 5 ( $32 \pm 1$ and $31 \pm 1$, respectively) than on days 1 and 2 ( $27 \pm 1$ and $28 \pm 1$, respectively), with days 0 and 3 (30 \pm 1 and $31 \pm 1$, respectively) being intermediate. Plasma total IGFBP activity $(\%)$ was higher $(P<0.04)$ on day $5(17.7 \pm 0.5)$ than on days 2 and 4 (15.4 and $16.2 \pm 0.5$, respectively), and was intermediate on days 0,1 and $3(17.0,17.0$, and 16.4 \pm 0.5 , respectively). Time of day did not contribute to variation in plasma IGF-I, and no treatment $x$ breed, treatment $x$ day of injection or breed $x$ day of injection interactions were detected for plasma IGF-I or total IGFBP activity.

\section{Ovarian and follicular characteristics at ovariectomy}

The number of follicles was significant as a covariate $(P<0.01)$ for ovarian mass, and when included in the model as such, ovaries of insulin-treated cows tended to be heavier than those of control cows $(23.0 \pm 1.7$ versus $17.7 \pm 1.7 \mathrm{~g} ; P<0.12)$. Initial analysis indicated that mean paired ovarian masses were greater $(P<0.01)$ in Brahman $(27.5 \pm 2.7 \mathrm{~g})$ than in Angus $(13.3 \pm 2.7 \mathrm{~g})$ cows. However, when the number of follicles 


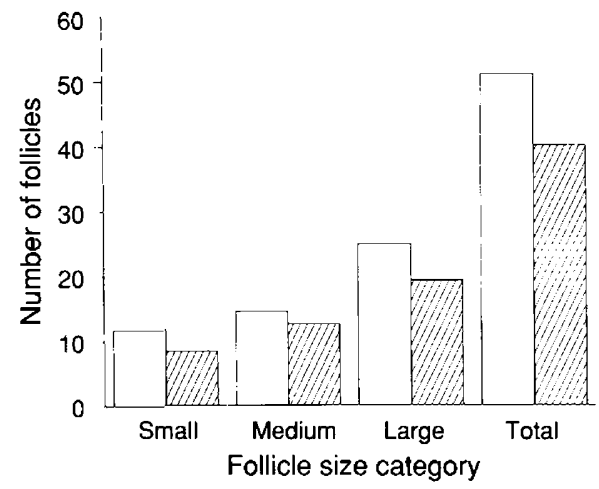

Fig. 3. Effect of treatment ( $(\square)$ control versus ( $\mathbb{T}_{\mathrm{W}}$ ) insulin) on number of follicles at ovariectomy on day 5 of study. Cows received FSH i.m. at $07: 00$ and $13: 00 \mathrm{~h}$ for 5 consecutive days (days $0-4$ ) with concomitant s.c. administration of saline (control) or long-acting bovine insulin $\left(0.25 \mathrm{iu} \mathrm{kg}^{-1}\right.$ body mass). The number of small $(1.0-3.9 \mathrm{~mm})$, medium $(4.0-7.9 \mathrm{~mm})$, large $(\geq 8.0 \mathrm{~mm})$ and total number of follicles did not differ between treatments.

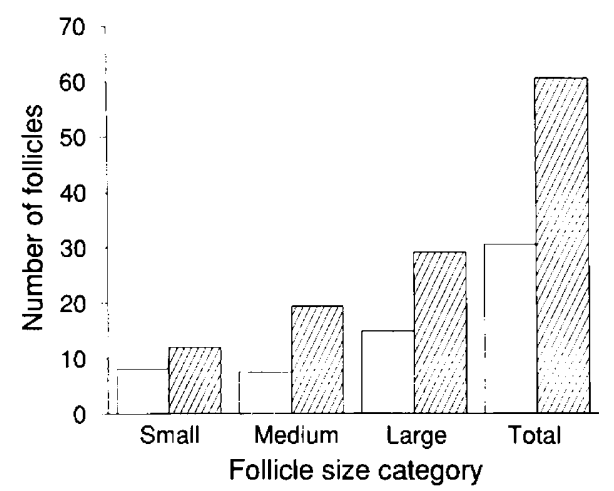

Fig. 4. Effect of breed (( $\square$ ) Angus versus ( follicles at ovariectomy on day 5 of study. Cows received FSH i.m. at 07:00 and 19:00 h for 5 consecutive days (days 0-4) with concomitant s.c. administration of saline (control) or long-acting bovine insulin $\left(0.25 \mathrm{iu} \mathrm{kg}{ }^{-1}\right.$ body mass). Brahman cows had a greater $(P<0.01)$ number of medium $(4.0-7.9 \mathrm{~mm})$ and total follicles than did Angus cows.

was included as a covariate in the statistical model, no breed effect was observed. No breed $x$ treatment interaction was detected for mean paired ovarian mass.

Treatment had no effect on the number of follicles, of any size category, at ovariectomy (Fig. 3). Brahman cows had more $(P<0.01)$ medium $(19.4 \pm 2.5)$ and total follicles $(60.5 \pm 5.5)$ than did Angus cows $(7.5 \pm 2.6$ medium follicles and $30.5 \pm 5.6$ total follicles) (Fig. 4).

The diameter of large follicles was greater $(P<0.05)$ in insulin-treated (11.4 $\pm 0.2 \mathrm{~mm}$ ) than in control cows $(10.6 \pm 0.1 \mathrm{~mm})$. Insulin treatment increased fluid volume $(\mu \mathrm{l})$ in large follicles above that of control values in Angus (660 \pm 47 versus $438 \pm 32$, respectively) but not in Brahman (589 \pm 29 versus $528 \pm 24$, respectively) cows (treatment $\times$ breed interaction, $P<0.05$ ). Diameter and fluid volume of large follicles were positively correlated $(r=0.62, P<0.01)$. The diameter of large follicles tended $(P<0.10)$ to be greater in Angus
$(11.2 \pm 0.2 \mathrm{~mm})$ than in Brahman $(10.8 \pm 0.1 \mathrm{~mm})$ cows. No treatment $\times$ breed interaction was detected for diameter of large follicles.

Follicle diameter and fluid volume of medium follicles were similar between treatments. However, the volume of fluid in medium follicles was greater $(P<0.01)$ in Brahman $(212 \pm 13 \mu \mathrm{l})$ than in Angus $(135 \pm 20 \mu \mathrm{l})$ cows. No treatment $x$ breed interaction was detected for diameter or volume of medium follicles. Follicle diameter of small follicles was similar between treatments and breeds, with no treatment $\times$ breed interaction.

\section{Follicular fluid hormones}

In medium follicles, the concentration of IGF-I in follicular fluid was greater $(P<0.01)$ in Brahman $\left(54 \pm 3 \mathrm{ng} \mathrm{m}^{-1}\right)$ than in Angus ( $32 \pm 4 \mathrm{ng} \mathrm{ml}^{-1}$ ) cows (Table 1). A treatment $\times$ breed interaction for follicular fluid IGF-I was detected in small and large follicles. In pooled samples from small follicles, follicular fluid IGF-I concentrations were lower in Angus cows treated with insulin than in control Angus cows, but were higher in insulin-treated Brahman cows than in control Brahman cows. Concentrations of IGF-I in follicular fluid from large individual follicles were reduced by insulin treatment in Angus cows but raised by insulin treatment in Brahman cows. Multivariate analysis of variance revealed a positive correlation $(r=0.78 ; \quad P<0.01)$ between plasma IGF-I on day 4 and follicular fluid IGF-I. Neither plasma IGF-I nor follicular fluid IGF-I were correlated with follicle diameter.

There were no treatment differences in IGFBP activity in medium or large follicles (Table 1). In medium follicles, IGFBP activity was higher in Angus than in Brahman (9.6 \pm 1.4 versus $5.4 \pm 1.0 \% 10 \mu \mathrm{l}^{-1} ; P<0.03$ ) cows.

Follicular fluid concentrations of oestradiol in medium and large follicles reflected a treatment $\times$ breed interaction $(P<0.05$ and $P<0.01$, respectively; Table 2 ). In the follicular fluid of medium follicles, insulin treatment increased concentrations of oestradiol in Brahman cows, and caused an increase in Angus cows. In large follicles, follicular fluid oestradiol was increased by exogenous insulin in both breeds, but by a greater magnitude in Angus than in Brahman cows. In medium and large follicles, Angus cows $\left(87 \pm 14\right.$ and $129 \pm 6 \mathrm{ng} \mathrm{ml}^{-1}$, respectively) possessed higher $(P<0.01)$ follicular fluid concentrations of oestradiol than did Brahman ( $45 \pm 9$ and $43 \pm 4 \mathrm{ng} \mathrm{ml}^{-1}$, respectively) cows (Table 2).

Administration of insulin decreased follicular fluid concentrations of progesterone in large follicles and resulted in decreased follicular fluid progesterone of medium follicles in Brahman but not in Angus cows (treatment $x$ breed interaction, $P<0.01$; Table 2). Brahman cows had higher $(P<0.01)$ follicular fluid progesterone in large follicles than did Angus cows.

The oestradiol:progesterone ratio in follicular fluid of large follicles from insulin-treated cows tended to be higher $(P<0.10)$ than that of control cows $(1.13 \pm 0.11$ versus $0.81 \pm 0.09$, respectively). In addition, the oestradiol: progesterone ratio in follicular fluid of large follicles was higher in Angus ( $1.23 \pm 0.03)$ than in Brahman $(0.71 \pm 0.02)$ cows. 
Table 1. Concentrations (ng $\mathrm{ml}^{-1}$ ) of insulin-like growth factor I (IGF-I) and IGF-binding protein activity $\left(\%(10 \mu \mathrm{l})^{-1}\right.$; IGFBP) in ovarian follicular fluid of superovulated control and insulin-treated Angus and Brahman cows ${ }^{a}$

\begin{tabular}{|c|c|c|c|c|c|c|c|c|}
\hline \multirow[b]{3}{*}{ Follicle size category } & \multirow[b]{3}{*}{$n$} & \multicolumn{4}{|c|}{ Breed and treatment } & \multicolumn{3}{|c|}{ Probability $^{b}$} \\
\hline & & \multicolumn{2}{|c|}{ Angus } & \multicolumn{2}{|c|}{ Brahman } & \multirow[b]{2}{*}{ TRT } & \multirow[b]{2}{*}{$\mathrm{BRD}$} & \multirow[b]{2}{*}{$\mathrm{TRT} \times \mathrm{BRD}$} \\
\hline & & Control & Insulin & Control & Insulin & & & \\
\hline \multicolumn{9}{|l|}{ IGF-I } \\
\hline Small & $37^{\mathrm{c}}$ & $65 \pm 14^{\mathrm{g}}$ & $23 \pm 18$ & $30 \pm 12$ & $59 \pm 12$ & 0.8 & 0.9 & 0.02 \\
\hline Medium (pooled) & $46^{d}$ & $12 \pm 13$ & $31 \pm 11$ & $42 \pm 9$ & $66 \pm 9$ & 0.2 & $<0.01$ & 0.8 \\
\hline Medium (individual) & $120^{\circ}$ & $25 \pm 5$ & $51 \pm 8$ & $44 \pm 3$ & $68 \pm 5$ & 0.2 & $<0.01$ & 0.9 \\
\hline Large & $601^{f}$ & $38 \pm 2$ & $31 \pm 3$ & $37 \pm 2$ & $60 \pm 2$ & 0.6 & $<0.01$ & $<0.01$ \\
\hline \multicolumn{9}{|l|}{ IGFBP } \\
\hline Medium (pooled) & 28 & $7.3 \pm 1.6$ & $3.2 \pm 2.2$ & $5.0 \pm 1.2$ & $5.5 \pm 1.3$ & 0.3 & 0.9 & 0.2 \\
\hline Medium (individual) & 39 & $9.6 \pm 1.6$ & $9.6 \pm 2.8$ & $5.8 \pm 1.0$ & $4.6 \pm 2.2$ & 0.9 & $<0.03$ & 0.8 \\
\hline Large & 86 & $7.2 \pm 0.9$ & $4.8 \pm 1.1$ & $5.7 \pm 0.9$ & $5.8 \pm 0.8$ & 0.5 & 0.6 & 0.2 \\
\hline \multicolumn{9}{|c|}{ 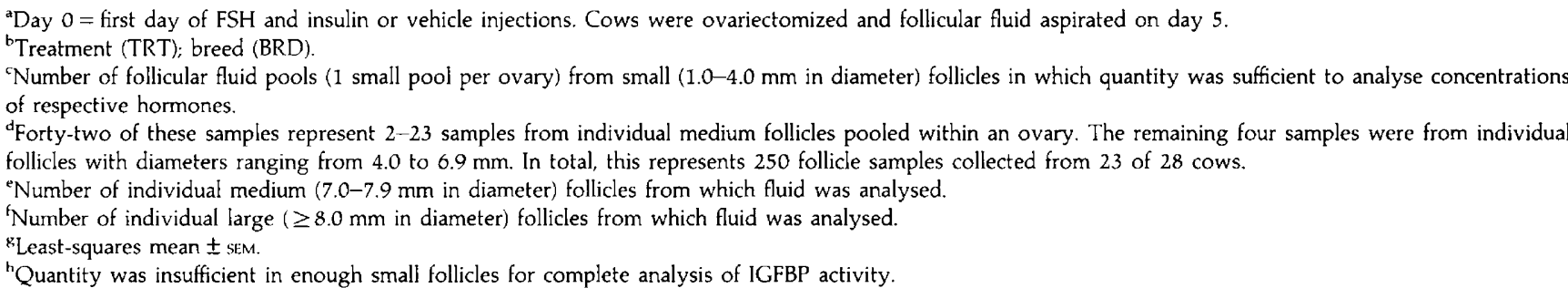 } \\
\hline
\end{tabular}

Table 2. Concentrations ( $\mathrm{ng} \mathrm{ml}^{-1}$ ) of oestradiol and progesterone in ovarian follicular fluid of superovulated control and insulin-treated Angus and Brahman cows ${ }^{a}$

\begin{tabular}{|c|c|c|c|c|c|c|c|c|}
\hline \multirow[b]{3}{*}{ Follicle size category } & \multirow[b]{3}{*}{$n$} & \multicolumn{4}{|c|}{ Breed and treatment } & \multicolumn{3}{|c|}{ Probability $^{\mathrm{b}}$} \\
\hline & & \multicolumn{2}{|c|}{ Angus } & \multicolumn{2}{|c|}{ Brahman } & \multirow[b]{2}{*}{ TRT } & \multirow[b]{2}{*}{ BRD } & \multirow[b]{2}{*}{$\mathrm{TRT} \times \mathrm{BRD}$} \\
\hline & & Control & Insulin & Control & Insulin & & & \\
\hline \multicolumn{9}{|l|}{ Oestradiol } \\
\hline Small & $37^{c}$ & $21 \pm 19^{g}$ & $68 \pm 20$ & $9 \pm 17$ & $27 \pm 19$ & 0.2 & 0.3 & 0.4 \\
\hline Medium (pooled) & $40^{d}$ & $46 \pm 31$ & $86 \pm 36$ & $14 \pm 22$ & $82 \pm 23$ & 0.6 & 0.9 & $<0.03$ \\
\hline Medium (individual) & $114^{\mathrm{e}}$ & $46 \pm 20$ & $159 \pm 30$ & $19 \pm 13$ & $71 \pm 20$ & 0.3 & $<0.01$ & 0.5 \\
\hline Large & $595^{f}$ & $39 \pm 6$ & $219 \pm 9$ & $18 \pm 5$ & $68 \pm 6$ & 0.08 & $<0.01$ & $<0.01$ \\
\hline \multicolumn{9}{|l|}{ Progesterone } \\
\hline Small & 26 & $50 \pm 29$ & $66 \pm 39$ & $53 \pm 25$ & $54 \pm 23$ & 0.9 & 0.6 & 0.7 \\
\hline Medium (pooled) & 36 & $60 \pm 57$ & $332 \pm 71$ & $122 \pm 41$ & $3 \pm 48$ & 0.5 & $<0.04$ & $<0.01$ \\
\hline Medium (individual) & 107 & $60 \pm 26$ & $72 \pm 46$ & $145 \pm 16$ & $55 \pm 26$ & 0.2 & $<0.01$ & 0.13 \\
\hline Large & 573 & $153 \pm 18$ & $65 \pm 27$ & $206 \pm 13$ & $77 \pm 16$ & 0.04 & $<0.01$ & 0.1 \\
\hline
\end{tabular}

\footnotetext{
aDay $0=$ first day of FSH and insulin or vehicle injections. Cows were ovariectomized and follicular fluid aspirated on day 5.

${ }^{\mathrm{b}}$ Treatment (TRT); breed (BRD).

'Number of follicular fluid pools ( 1 small pool per ovary) from small (1.0-4.0 mm in diameter) follicles in which quantity was sufficient to analyse concentrations of respective hormones.

${ }^{\mathrm{d} F o r t y-t w o}$ of these samples represent $2-23$ samples from individual medium follicles pooled within an ovary and the four remaining samples were from individual follicles with diameters ranging from 4.0 to $6.9 \mathrm{~mm}$. In total, this represents 250 follicle samples collected from 23 of 28 cows.

eNumber of individual medium $(7.0-7.9 \mathrm{~mm}$ in diameter) follicles from which fluid was analysed.

${ }^{f}$ Number of individual large ( $\geq 8.0 \mathrm{~mm}$ in diameter) follicles from which fluid was analysed.

${ }^{8}$ Least-squares mean $\pm \mathrm{sEM}$.
}

Follicular fluid IGF-I and IGFBP activity were positively correlated $(r=0.43$ and 0.45 , respectively; $P<0.01$ ) with follicular progesterone; and follicular fluid IGF-I was negatively correlated $(r=-0.28 ; P<0.01)$ with the oestradiol: progesterone ratio in large follicles.

\section{Comparisons between oestrogen-active and oestrogen-inactive} follicles

Five hundred and sixty large follicles contained quantities of fluid sufficient for determination of oestradiol and progesterone 
Table 3. Concentrations ( $\mathrm{n} \mathrm{m}^{-1}$ ) of insulin-like growth factor I (IGF-I), oestradiol, progesterone, and IGF binding protein activity $\left(\%(10 \mu \mathrm{I})^{-1}\right.$; IGFBP $)$ in ovarian follicular fluid of large $(\geq 8.0 \mathrm{~mm})$ oestrogen-active and oestrogen-inactive follicles, $\mathrm{s}^{\mathrm{a}, \mathrm{b}}$ in superovulated control and insulin-treated Angus and Brahman cows ${ }^{c}$

\begin{tabular}{|c|c|c|c|c|c|c|c|}
\hline \multirow[b]{3}{*}{ Oestradiol status } & \multicolumn{4}{|c|}{ Breed and treatment } & \multicolumn{3}{|c|}{ Probability $^{d}$} \\
\hline & \multicolumn{2}{|c|}{ Angus } & \multicolumn{2}{|c|}{ Brahman } & \multirow[b]{2}{*}{ TRT } & \multirow[b]{2}{*}{$\mathrm{BRD}$} & \multirow[b]{2}{*}{$\mathrm{TRT} \times \mathrm{BRD}$} \\
\hline & Control & Insulin & Control & Insulin & & & \\
\hline \multicolumn{8}{|l|}{ IGF-I } \\
\hline Oestrogen-active & $17 \pm 5^{e}$ & $29 \pm 3$ & $30 \pm 5$ & $53 \pm 3$ & 0.2 & $<0.01$ & 0.2 \\
\hline Oestrogen-active ${ }^{f}$ & - & - & - & - & - & - & - \\
\hline Oestrogen-inactive & $7.8 \pm 1.3$ & $8.3 \pm \quad 3.0$ & $5.4 \pm 1.1$ & $5.3 \pm 1.8$ & 0.9 & 0.13 & 0.9 \\
\hline \multicolumn{8}{|l|}{ Oestradiol } \\
\hline Oestrogen-active & $63 \pm 38$ & $235 \pm 23$ & $52 \pm 42$ & $85 \pm 21$ & 0.4 & $<0.01$ & 0.2 \\
\hline Oestrogen-inactive & $27 \pm 2$ & $89 \pm 7$ & $17 \pm 1$ & $16 \pm 4$ & 0.6 & $<0.01$ & $<0.01$ \\
\hline
\end{tabular}

${ }^{2}$ Oestrogen-active follicles $=$ ratio of the concentration of oestradiol:concentration of progesterone $>1.0(n=165)$; oestrogen-inactive follicles $=$ ratio $<1.0(n=395)$.

'Oestrogen-active: Angus-control, $n=46$; Angus-insulin, $n=80$; Brahman-control, $n=18$; Brahman-insulin, $n=52$.

Oestrogen-inactive: Angus-control, $n=72$; Angus-insulin, $n=5$; Brahman-control, $n=201$; Brahman-insulin, $n=124$.

${ }^{\circ}$ Day $0=$ first day of FSH and insulin or vehicle injections; cows were ovariectomized and follicular fluid aspirated on day 5.

${ }^{\mathrm{d}}$ Treatment (TRT); breed (BRD).

${ }^{e}$ Least-squares mean $\pm \mathrm{SEM}$.

${ }^{\text {f}} \mathrm{Quantity}$ was insufficient in enough samples for complete analysis of IGFBP activity.

concentrations, allowing classification of the follicles, as oestrogen-active or oestrogen-inactive to be made, according to the oestradiol:progesterone ratio. Treatment did not affect the number of oestrogen-active follicles (3.0 and $8.5 \pm 2.3$ oestrogen-active follicles per cow for control and insulintreated animals, respectively); however, the percentage of large follicles that were oestrogen-active was higher $(P<0.05)$ in insulin-treated $(54 \pm 4.9 \%)$ than in control $(25 \pm 4.5 \%)$ cows. The absolute number and the percentage of oestrogen-active follicles were similar between breeds (7.1 versus $4.4 \pm 2.1$ oestrogen-active follicles per cow and 49 versus $29 \pm 10 \%$ for Angus and Brahman cows, respectively). Control cows tended to possess a greater $(P<0.06)$ number of oestrogen-inactive follicles than did insulin-treated cows (19.4 versus $9.5 \pm 2.3$ oestrogen-inactive follicles per cow), and Brahman cows had a greater $(P<0.01)$ number of oestrogen-inactive follicles than did Angus cows (23.0 versus $6.0 \pm 3.9$ oestrogen-inactive follicles per cow).

In oestrogen-active follicles, follicular fluid IGF-I was higher $(P<0.01)$ in Brahman $\left(41 \pm 3 \mathrm{ng} \mathrm{ml}^{-1}\right)$ than in Angus (23 $\pm 3 \mathrm{ng} \mathrm{ml}^{-1}$ ) cows (Table 3). Follicle diameter was not significant as a covariate in the follicular fluid IGF-I analysis in either oestrogen-status category. A positive correlation was found between follicular fluid concentrations of IGF-I and progesterone in oestrogen-active $(r=0.36 ; P<0.01)$ and oestrogen-inactive $(r=0.41 ; P<0.01)$ follicles. Follicle diameter $(P<0.01)$ and follicular fluid IGF-I $(P<0.05)$ were lower in oestrogen-active $(10.6 \pm 0.16 \mathrm{~mm} \text { and } 33 \pm 1.9 \mathrm{ng} \mathrm{m})^{-1}$, respectively) than in oestrogen-inactive (11.1 $\pm 0.12 \mathrm{~mm}$ and $49 \pm 1.8 \mathrm{ng} \mathrm{ml}^{-1}$, respectively) follicles.
In oestrogen-active and oestrogen-inactive follicles, Angus cows had higher $(P<0.01)$ concentrations of follicular fluid oestradiol (170 \pm 19 and $58 \pm 4 \mathrm{ng} \mathrm{ml}^{-1}$, respectively) than did Brahman cows ( $63 \pm 19$ and $17 \pm 2 \mathrm{ng} \mathrm{ml}^{-1}$, respectively) (Table 3). Follicle diameter was significant as a covariate for follicular fluid oestradiol in oestrogen-active, but not oestrogen-inactive, follicles.

Treatment did not influence follicular fluid concentrations of progesterone in oestrogen-active follicles (Table 3). In oestrogen-inactive follicles, follicular fluid progesterone tended to be higher $(P<0.10)$ in control than in insulin-treated cows. Follicle diameter contributed to variation $(P<0.02)$ in follicular fluid progesterone as a covariate in oestrogen-active and oestrogen-inactive follicles.

Oestradiol:progesterone ratios in oestrogen-active follicles were higher $(P<0.01)$ in Angus $(1.60 \pm 0.07)$ than in Brahman ( $1.41 \pm 0.07)$ cows. In oestrogen-inactive follicles, the oestradiol:progesterone ratio was higher in insulin-treated than control in Angus ( $0.96 \pm 0.08$ versus $0.67 \pm 0.02$, respectively), but not Brahman (0.59 \pm 0.04 versus $0.55 \pm 0.01$, respectively) cows (treatment $\times$ breed interaction, $P<0.05$ ). When used as a covariate, follicle diameter did not contribute to variation in the oestradiol:progesterone ratio in oestrogen-active or oestrogen-inactive follicles.

\section{Discussion}

The results reported here indicate that insulin increases the diameter of large follicles but has no effect on numbers of 
follicles in superovulated Angus and Brahman cows, increases follicular fluid oestradiol and decreases follicular fluid progesterone in large follicles of both breeds, increases the percentage of large follicles that are oestrogen-active, increases follicular fluid concentrations of IGF-I in small and large follicles of Brahman cows, but decreases follicular fluid IGF-I in small and large follicles of Angus cows, and does not influence IGFBP activity in medium or large follicles of either breed. Concentrations of IGF-I in plasma and follicular fluid of Brahman cows were higher than that in Angus cows, whereas oestradiol content of medium and large follicles was lower in Brahman than in Angus cows. The follicular fluid progesterone in large follicles was higher in Brahman cows than in Angus cows and total number of follicles was greater in Brahman cows.

Insulin treatment reduced plasma glucose concentrations as expected, but did not affect the number of follicles recruited after superovulation resulting from treatment with FSH. However, insulin treatment increased the size (diameter and volume) of large follicles in Angus and Brahman cows. Harrison and Randel (1986) showed that administration of insulin increased the ovulation rate in response to FSH in energy-deprived Brangus heifers, and Langhout et al. (1991) showed that insulin increased bovine granulosa cell proliferation in vitro. These effects of insulin are thought to be direct actions of insulin mediated through insulin receptors on ovarian cells (Poretsky and Kalin, 1987). Our findings suggest that insulin has a stimulatory effect on follicle growth in cattle.

The present study is the first in vivo report in cattle to show a stimulatory effect of insulin on oestradiol production by follicles and is consistent with in vivo studies in cyclic gilts that showed that insulin treatment increases intrafollicular oestradiol concentrations (Matamoros et al., 1990). These insulin-induced changes in oestradiol concentrations in follicular fluid appear to have occurred independently of the changes in concentrations of IGF-I in follicular fluid, as oestradiol and IGF-I concentrations were not significantly correlated. Results from cultured granulosa cells evaluating the effect of insulin on oestradiol production have varied with species and studies: insulin enhanced FSH-stimulated oestrogen production in cultured rat granulosa cells (Adashi et al., 1985; Davoren et al., 1985), whereas in cultured pig granulosa cells, insulin alone either inhibited (Veldhuis et al., 1983) or had no effect (Maruo et al., 1988) on oestrogen production. In cultured, FSH-treated granulosa cells from bovine follicles, insulin treatment at doses of $1-1000 \mathrm{ng} \mathrm{ml}^{-1}$ resulted in a 1.7 - to 3.9 -fold increase in oestradiol production in cells from small $(1-5 \mathrm{~mm})$ follicles, and a 1.4- to 1.9-fold increase in oestradiol production in cells from large follicles (Spicer et al., 1993, 1994). Collectively, in vivo and in vitro studies support a stimulatory role for insulin in oestradiol production by follicles in cattie.

Follicular fluid concentrations of oestradiol in medium, large, and in large oestrogen-active follicles of Angus cows were higher than those of Brahman cows. This finding is in agreement with Segerson et al. (1984) who reported higher serum concentrations of oestradiol in Angus than in Brahman cows. This breed difference may be due, in part, to the higher concentrations of IGF-I in follicular fluid of Brahman cows, as, IGF-I has been shown to inhibit basal and FSH-stimulated oestradiol production by granulosa cells from small bovine follicles in vitro (Spicer et al., 1993). More recently, IGF-I has been shown to inhibit insulin-stimulated oestradiol production by granulosa cells from both small and large follicles in vitro (Spicer et al., 1994). However, other factors (for example, increased IGFBP activity) could be involved in vivo, and thus the reason why oestradiol concentrations were lower in Brahman than in Angus cows of the present study is uncertain.

Exogenous insulin decreased concentrations of progesterone in large follicles of both breeds of cattle. As follicular fluid oestradiol increased in both breeds of cattle with insulin treatment, it is possible that more progesterone is being used by the theca for androgen production and subsequent oestradiol production by the membrana granulosa as previously suggested (Fortune, 1986; Fortune and Quirk, 1988). However, the inhibitory effect of insulin on progesterone was primarily expressed in oestrogen-inactive follicles of Brahman cows; insulin had no effect on progesterone content of oestrogenactive follicles. In these same oestrogen-inactive follicles of Brahman cows, oestradiol concentrations and IGFBP values were not affected by insulin treatment. Thus, the mechanism for decreased progesterone in insulin-treated cows remains to be determined but it does not appear to involve IGFBP. In studies with PMSG-treated gilts, follicular fluid progesterone concentrations were unaffected by insulin treatment (Matamoros et al., 1991) and did not differ between diabetic and normal gilts (Meurer et al., 1991). In contrast, previous work in vitro indicated that insulin and IGF-I enhance progesterone production by rat (Davoren et al., 1985), porcine (Veldhuis et al., 1986; Maruo et al., 1988) and bovine (Langhout et al., 1991; Spicer et al., 1993) granulosa cells, whereas IGFBP inhibits oestradiol and progesterone production by rat granulosa cells (Ui et al., 1989; Liu et al., 1993). In agreement with previous reports in women (Jimena et al., 1992) and cattle (Spicer et al., 1988; Spicer and Enright, 1991), in the present study IGF-I and progesterone concentrations were positively correlated in oestrogen-active and oestrogen-inactive follicles.

Healthy, preovulatory follicles are characterized by high quantities of oestradiol and high oestradiol:progesterone ratios (Ireland and Roche, 1983a,b; Kruip and Dieleman, 1985). In the present study, treatment with insulin increased the percentage of large follicles that were oestrogen-active and tended to increase the oestradiol:progesterone ratio in large follicles, the latter probably due to both an increase in follicular fluid oestradiol and a decrease in follicular fluid progesterone. This finding follows the pattern, reported by Meurer et al. (1991), in which the follicular fluid ratio of oestradiol:progesterone in follicles $\geq 7 \mathrm{~mm}$ was lower in diabetic than in normal gilts. Oestrogen-active follicles (oestradiol concentrations approximately three times higher than those of oestrogen-inactive follicles) had lower $(P<0.01)$ follicular fluid concentrations of IGF-I than did oestrogen-inactive follicles, and insulin increased oestradiol concentrations of oestrogen-inactive follicles in Angus, but not Brahman cows. These changes occurred in the presence of unchanging IGFBP activity. Spicer et al. (1988) found no difference in IGF-I values between oestrogen-active and oestrogen-inactive follicles of postpartum anovulatory cows and suggested that follicular fluid IGF-I is not a limiting factor for ovarian follicular oestradiol production in vivo.

Our finding that Brahman cows possess more medium follicles and approximately twice the number of total follicles 
than do Angus cows is in agreement with Segerson et al. (1984), who reported a greater (almost double) number of follicles with diameters less than $5 \mathrm{~mm}$ in Brahman cows that were not superovulated than in Angus cows that were not superovulated. It is possible that the higher follicular fluid concentrations of IGF-I in Brahman cows enhanced the effects of FSH and resulted in more follicles than in Angus cows. Whether the greater number of follicles possessed by Brahman cows in the present study would result in more ovulations is not known. Staigmiller et al. (1979) found that crossbred cows that lost $0.15 \mathrm{~kg}$ per day over the preceding 92 days possessed more large follicles at ovariectomy than did cows that had gained $0.63 \mathrm{~kg}$ per day over that same period. Although the weight loss in the present study occurred over a much shorter period (from day 0 to day 5), the greater number of follicles found on ovaries from Brahman cows may have been associated with the greater loss of body mass that was observed in the Brahman compared with the Angus cows. The loss of body mass observed in cows during the present study was probably due to stress associated with the frequency of handling, blood collection and treatment injections (every $6 \mathrm{~h}$ for 5 days).

We observed that insulin increased concentrations of IGF-I in follicular fluid but had no effect on plasma concentrations of IGF-I. This finding is in agreement with a recent study in prepubertal gilts treated with PMSG (Matamoros et al., 1991). However, IGF-I increased only in the fluid of small and large follicles of Brahman cows, and decreased in the fluid of large follicles of Angus cows. Reasons for these differences between Brahman and Angus cows are unclear but may be due, in part, to inherent breed differences in initial plasma or follicular fluid concentrations of IGF-I or to breed differences in responsiveness of the ovaries to insulin. Plasma IGF-I was positively correlated with the percentage of Brahman breeding in steers (Hammond et al., 1990). Additional research will be required to determine whether the stimulatory effect of insulin on follicle growth is mediated by insulin-induced changes in intrafollicular IGF-I.

Generally, IGF-I and IGFBP are secreted concomitantly into the systemic circulation (Sara and Hall, 1990) and this is consistent with the results of the present study. Specifically, Brahman cows had approximately $10 \%$ greater IGFBP activity and two-fold greater IGF-I concentrations than do Angus cows. Similar two-fold differences in concentrations of IGF-I in follicular fluid of medium and large follicles existed. In contrast, no breed differences were observed for IGFBP values in pools of follicular fluid from small or medium follicles or individual large follicles. Because the breed differences in IGFBP activity were small compared with those of IGF-I, we suggest that differences in follicular fluid oestradiol and progesterone between Angus and Brahman cattle are due mainly to differences in the concentration of IGF-I rather than of IGFBP.

Other studies have found a positive relationship between follicular fluid IGF-I and follicle size in pigs (Hammond et al., 1985; Spicer et al., 1992) and cattle (Spicer et al., 1988; Echternkamp et al., 1990; Spicer and Enright, 1991). However, in the present study, follicular fluid IGF-I was not correlated with follicle diameter. One reason for this discrepancy may be the superovulatory doses of FSH used in this study; in previous studies animals were not treated with exogenous gonadotrophins. In addition, Meurer et al. (1991) reported an absence of correlation between follicular fluid IGF-I and follicular diameter in diabetic PMSG-treated gilts.

In summary, although exogenous insulin did not increase the number of follicles detected at ovariectomy, the findings that insulin increased the diameter of large follicles, increased follicular fluid oestradiol in medium and large follicles and decreased follicular fluid progesterone in large follicles, and increased follicular fluid IGF-I in small and large follicles of Brahman cows indicates that this treatment affected follicular function to some extent. Whether insulin treatments can be used to enhance ovulation rate, oocyte quality or the number of transferrable embryos after superovulation will require further work.

This manuscript was published as Florida Agricultural Experiment Station Journal Series No. R-03330. Approved for publication by the Director, Oklahoma Agricultural Experiment Station; this research was supported in part under project H-2088 (to L. J. Spicer). Appreciation is expressed to: R. A. Bellows, E. L. Adams, E. J. Bowers, S. C. Howard, E. V. Rooks and M. L. Rooks for technical assistance; the National Hormone and Pituitary Program (Baltimore, MD) for the antiserum; and N. R. Mason (Lilly Research Laboratories, Indianapolis, IN) for the generous donation of oestradiol antiserum. Product names are necessary to report factually on available data; however, the USDA neither guarantees nor warrants the standard of these products to the exclusion of others.

\section{References}

Adashi EY, Resnick CE, D'Ercole AJ, Svoboda ME and Van Wyk JJ (1985) Insulin-like growth factors as intraovarian regulators of granulosa cell growth and function Endocrine Reviews 6 400-420

Allen WR, Nilsen-Hamilton M and Hamilton RT (1981) Insulin and growth factors stimulate rapid post-translational changes in glucose transport in ovarian granulosa cells Journal of Cell Physiology 108 15-24

Cox NM, Stuart MJ, Althen TG, Bennett WA and Miller HW (1987) Enhancement of ovulation rate in gilts by increasing dietary energy and administering insulin during follicular growth Journal of Animal Science 64 507-516

Czech MP (1984) New perspectives on the mechanism of insulin action Recent Progress in Hormone Research $40347-377$

Davoren JB, Hsueh AJ and $\mathrm{Li}$ CH (1985) Somatomedin C augments FSHinduced differentiation of cultured rat granulosa cells American Journal of Physiology 249 E26-E33

Echternkamp SE, Spicer LJ, Gregory KE, Canning SF and Hammond JM (1990) Concentrations of insulin-like growth factor-I in blood and ovarian follicular fluid of cattle selected for twins Biology of Reproduction 43 8-14

Fortune JE (1986) Bovine theca and granulosa cells interact to promote androgen production Biology of Reproduction 35 292-299

Fortune JE and Quirk SM (1988) Regulation of steroidogenesis in bovine preovulatory follicles journal of Animal Science 66 I-8

Gochman N and Schmitz JM (1972) Application of a new peroxide indicator reaction to the specific, automated determination of glucose oxidase Clinical Chemistry 18 943-950

Guidice LC (1992) Insulin-like growth factors and ovarian follicular development Endocrine Reviews 13 641-669

Hammond AC, Elsasser TH, Kunkle WE, Rumsey TS, Williams MJ and Butts WT (1990) Effects of winter nutrition and summer pasture or a feedlot diet on plasma insulin-like growth factor I (IGF-I) and the relationship between circulating concentrations of IGF-I and thyroid hormones in steers Domestic Animal Endocrinology 7 465-476

Hammond JM, Baranao JLS, Skaleris D, Knight AB, Romanus JA and Rechler MM (1985) Production of insulin-like growth factors by ovarian granulosa cells Endocrinology 117 2553-2555

Hammond JM, Mondschein IS, Samaras SE and Canning SF (1991) The ovarian insulin-like growth factors, a local amplification mechanism for steroidogenesis and hormone action Journal of Steroid Biochemistry and Molecular Biology $40411-418$ 
Harrison LM and Randel RD (1986) Influence of insulin and energy intake on ovulation rate, luteinizing hormone and progesterone in beef heifers journal of Animal Science 63 1228-1235

Ireland Jf and Roche JF (1983a) Development of nonovulatory antral follicles in heifers: changes in steroids in follicular fluids and receptors for gonadotropins Endocrinology 112 150-156

Ireland JJ and Roche JF (1983b) Growth and differentiation of large antral follicles after spontaneous Juteolysis in heifers: changes in concentration of hormones in follicular fluid and specific binding of gonadotropins to follicles Journal of Animal Science 57 157-167

Jimena P, Castilla JA, Peran F, Molina R, Ramirez JP, Acebal M, Vergara F and Herruzo A (1992) Insulin and insulin-like growth factor I in follicular fluid after induction of ovulation in women undergoing in vitro fertilization Journal of Reproduction and Fertility $96641-647$

Kirkwood RN, Thacker PA, Korchinski RS, Gonzalez A and Laarveld B (1991) Effect of premating injections of insulin on fertility and prolificacy of ewes Canadian Journal of Animal Science 71 241-244

Kruip ThAM and Dieleman SJ (1985) Steroid hormone concentrations in the fluid of bovine follicles relative to size, quality and the stage of the estrous cycle Theriogenology 24 395-408

Langhout DJ, Spicer LJ and Geisert RD (1991) Development of a culture system for bovine granulosa cells: effects of growth hormone, estradiol, and gonadotropins on cell proliferation, steroidogenesis, and protein synthesis Journal of Animal Science 69 3321-3334

Liu X, Malkowski M, Guo Y, Erickson GF, Shimasaki S and Ling N (1993) Development of specific antibodies to rat insulin-like growth factor-binding proteins (IGFBP-2 to -6 ): analysis of IGFBP production by rat granulosa cells Endocrinology 132 1176-1183

Maruo T, Hayashi M, Matsuo H, Ueda Y, Morikawa H and Mochizuki M (1988) Comparison of the facilitative roles of insulin and insulin-like growth factor I in the functional differentiation of granulosa cells: in vitro studies with the porcine model Acta Endocrinologica 117 230-240

Matamoros IA, Cox NM and Moore AB (1990) Exogenous insulin and additional energy affect follicular distribution, follicular steroid concentrations, and granulosa cell human chorionic gonadotropin binding in swine Biology of Reproduction 43 1-7

Matamoros IA, Cox NM and Moore AB (1991) Effects of exogenous insulin and body condition on metabolic hormones and gonadotropin-induced follicular development in prepuberal gilts Journal of Animal Science $692081-2091$

Meurer KA, Cox NM, Matamoros IA and Tubbs RC (1991) Decreased follicular steroids and insulin-like growth factor-I and increased atresia in diabetic gilts during follicular growth stimulated with PMSG Journal of Reproduction and Fertility 91 187-196

Moses AC, Nissley SP, Passamani J and White RM (1979) Further characterization of growth hormone-dependent somatomedin-binding proteins in rat serum and demonstration of somatomedin-binding proteins produced by rat liver cells in culture Endocrinology 104 536-546

Peacock FM, Koger M, Kirk WG, Hodges EM and Warnick AC (1971) Reproduction in Brahman, Shorthorn and crossbred cows on different pasture programs Journai of Animal Science 33 458-465

Peacock FM, Koger M, Crockett JR and Warnick AC (1977) Reproductive performance and crossbreeding Angus, Brahman and Charolais cattle Journal of Animal Science 44 729-733

Peluso JJ and Hirschel MD (1987) Role of gonadotropins and insulin in controlling steroidogenesis and growth of antral bovine follicles in perifusion culture Theriogenology 28 503-512
Poretsky L and Kalin MF (1987) The gonadotropic function of insulin Endocrine Reviews 8 132-141

Prior RL and Smith SB (1983) Role of insulin in regulating amino acid metabolism in normal and alloxan-diabetic cattle Joumal of Nutrition 113 1016-1031

Randel RD (1984) Seasonal effects on female reproductive function in the bovine (Indian breeds) Theriogenology 21 170-185

Reynolds WL, DeRouen TM, Moin S and Koonce KL (1979) Factors affecting pregnancy rate of Angus, Zebu and Zebu-cross cattle Journal of Animal Science 48 1312-1321

Sara VR and Hall K (1990) Insulin-like growth factors and their binding proteins Physiological Reviews 70 591-614

SAS (1985) SAS/STAT Guide for personal computers. Statistical Analysis System Institute, Cary. NC

Savion N, Lui GM, Laherty R and Gospodarowicz D (1981) Factors controlling proliferation and progesterone production by bovine granulosa cells in serum-free medium Endocrinology 109 409-420

Segerson EC, Hansen TR, Libby DW, Randel RD and Getz WR (1984) Ovarian and uterine morphology and function in Angus and Brahman cows Journal of Animal Science 59 1026-1046

Spicer LJ and Enright WJ (1991) Concentrations of insulin-like growth factor $I$ and steroids in follicular fluid of preovulatory bovine ovarian follicles: effect of daily injections of a growth hormone-releasing factor analog and(or) thyrotropin-releasing hormone Journal of Animal Science 69 1133-1139

Spicer LJ, Echternkamp SE, Canning SF and Hammond JM (1988) Relationship between concentrations of immunoreactive insulin-like growth factor-I in follicular fluid and various biochemical markers of differentiation in bovine antral follicles Biology of Reproduction 39 573-580

Spicer LJ, Klindt J, Buonomo FC, Maurer R, Yen JT and Echternkamp SE (1992) Effect of porcine somatotropin on number of granulosa cell luteinizing hormone/human chorionic gonadotropin receptors, oocyte viability, and concentrations of steroids and insulin-like growth factors I and Il in follicular fluid of lean and obese gilts Journal of Animal Science 70 3149-3157

Spicer LJ, Alpizar E and Echternkamp SE (1993) Effects of insulin, insulin-like growth factor-I (IGF-I) and gonadotropins on bovine granulosa cell proliferation, progesterone production, estradiol production and(or) IGF-I production in vitro Journal of Animal Science 71 1232-1241

Spicer LJ, Alpizar E and Stewart RE (1994) Evidence for an inhibitory effect of insulin-like growth factor-I and -II on insulin-stimulated steroidogenesis by nontransformed ovarian granulosa cells Endocrine 2 735-739

Staigmiller RB, Short RE, Bellows RA and Carr JB (1979) Effect of nutrition on response to exogenous FSH in beef cattle Journal of Animal Science $\mathbf{4 8}$ 1182-1190

Ui M, Shimonaka M, Shimasaki S and Ling N (1989) An insulin-like growth factor-binding protein in ovarian follicular fluid blocks follicle-stimulating hormone-stimulated steroid production by ovarian granulosa cells Endocrinology 125 912-916

Veldhuis JD, Kolp LA, Toaff ME, Strauss JF, III and Demers LM (1983) Mechanisms subserving the trophic actions of insulin on ovarian cells: in vitro studies using swine granulosa cells Joumal of Clinical Investigation 72 1046-1057

Veldhuis JD, Rodgers RJ and Furlanetto RW (1986) Synergistic actions of estradiol and the insulin-like growth factor somatomedin- $\mathrm{C}$ on swine ovarian (granulosa) cells Endocrinology 119 530-538 